\title{
Review of some recent observations on 'glandular fever cells'
}

\author{
R. L. CARTER \\ From the Department of Pathology, The Radcliffe Infirmary, Oxford
}

Pathologists have long been familiar with the curious mononuclear cells which occur in the blood in infectious mononucleosis but until relatively recently most accounts have been largely concerned with morphological aspects. Other methods of investigation-electron microscopy, cytochemistry, autoradiography, and various immunological procedures - have now been used in more detailed studies of these cells, the results of which provide the main basis for this review. The material is presented in two sections. Part I deals principally with the morphology, ultrastructure, and cytochemistry of the atypical cells, their proliferative activity and possible immunological functions. In Part II, these observations are used in a discussion of three more general topics: the nature of the atypical cells, their possible origin, and their relationship to leukaemic cells.

Two problems arise in any study of infectious mononucleosis: the selection of diagnostic criteria and the choice of a suitable name for the atypical cells. There is now reasonable agreement that clinical, haematological, and serological criteria should all be satisfied before the diagnosis of infectious mononucleosis is made and this policy has been followed here. The nomenclature of the atypical cells is more difficult. Their occurrence in a wide variety of clinical conditions as well as in normal subjects (Efrati and Rozenszajn, 1960; Giacardy and Giacardy, 1961; Pearmain and Lycette, 1963) illustrates the inadequacies of 'glandular fever cells' and of 'virocytes' (Litwins and Leibowitz, 1951); 'atypical lymphocytes' may, by implication, be too restrictive a term, and the various hybrid names which abound in the older literature-lymphocytic plasma cells, lymphomonocytes, lymphatic monocytes, etc.-are confusing and often conflicting. They are referred to here as 'atypical mononuclear cells', a clumsy term but one which is at least noncommital.

\section{PART I}

\section{MORPHOLOGY}

The appearance of atypical mononculear cells in conventionally stained blood films has been repeatedly described and will not be considered in detail although three purely practical points are worth stressing. First, it is essential to have smears of the highest quality: films which are unevenly or thickly spread or heavily stained are quite useless for adequate appraisal of morphological details in the atypical cells. Secondly, the cells are particularly sensitive to the distorting effects of anticoagulants and all smears should be made as quickly as possible. After two-and-a-half to three hours' contact with E.D.T.A. or heparin at room temperature, an increasing number of cells develop various abnormalities, such as marked irregularities of the cell outline and of the nucleus, alterations in nuclear chromatin, and increased cytoplasmic vacuolation. Quite apart from adding to the difficulties in diagnosis, these various changes also obtrude into research procedures which make use of white cell concentrates. The preservation of fine cellular detail in autoradiographs, for example, is often not entirely satisfactory. The preparation of leucocyte concentrates illustrates the third point, that atypical mononuclear cells are also easily damaged mechanically, especially during centrifugation. Some of this fragility may be the consequence of previous contact with anticoagulants, but a proportion of atypical cells is also regularly damaged in blood which has been defibrinated by shaking: normal leucocytes are usually unaffected by this procedure.

Even when films are prepared under optimal conditions, the most striking feature of the atypical cells is their pleomorphism. This has two important implications. First, schemes whereby the cells are classified into various groups on purely morphological grounds are necessarily of doubtful value: it is probable, for example, that the Downey types I-III came to be applied far more rigidly than their author originally intended ('Each case shows minor variations indicating gradations between the types. . . This shows that the division of the cases into three types is entirely superficial ... Downey and McKinlay, 1923). Secondly, morphological criteria are of limited value in efforts to define the nature of the atypical cells, and examination of any large 
series of films indicates how difficult it is to categorize all the cells seen as lymphocytic, monocytic, or plasmacytic in origin. Attempts to do this have resulted in a bizarre list of alternative and often conflicting names for the atypical cells which merely confuse the situation still further.

\section{ULTRASTRUCTURE}

A few electron microscopy studies of the atypical mononuclear cells clarify the picture to some extent (Reinauer, 1961; Paegle, 1961; Inman and Cooper, 1965), although it must be admitted that the account by Reinauer, which includes lymph node material, is not easy to evaluate. Only one (low) Paul-Bunnell titre is given and bewildering numbers of different cell types are differentiated on electron-microscopic criteria without parallel descriptions of their morphology in the light microscope $e^{1}$. Clearer results were presented by Paegle (1961), who described a remarkably consistent ultrastructure in the circulating atypical mononuclear cells, despite their pleomorphism in conventional preparations. Apart from their larger size, most of the cells showed the general electron-microscopic features of lymphocytes and the few differences which were noted were of a relatively minor kind. Thus the atypical cells showed larger and more indented nuclei, an increase in the number and size of the mitochondria, and increased numbers of compound vacuoles and granules, none of which were sufficiently prominent to constitute a clear-cut distinction from normal lymphocytes. A few atypical mononuclear cells were also present with smaller mitochondria and rather more endoplasmic reticulum which resembled monocytes, but in the great majority of cases the endoplasmic reticulum and Golgi apparatus were poorly developed. Complex arrangements of these structures comparable to those found in plasma cells were never seen, a point which is of importance when considering possible immunological roles for the atypical cells, especially the synthesis of antibody (see section 5).

Inman and Cooper (1965) demonstrated a close similarity between the ultrastructure of atypical mononuclear cells and lymphocytes which have been transformed by phytohaemagglutinin (P.H.A.), 'P.H.A. cells'. They emphasize the loosely-arranged nuclear chromatin, the wide irregular nuclear membrane, and the increased numbers of mitochondria which occur in both cells types; unlike Paegle, Inman and Cooper also consider that the Golgi zone is moderately increased in atypical mononuclear

${ }^{1}$ These include reticular monoblasts and monocytes, histiocytic monocytes, myeloic monocytes, lymphatic stem cells, atypical lymphoblasts, atypical lymphocytes, and atypical plasma cells. cells. Some of these changes are clearly associated with the active synthesis of DNA which is a common feature of both types of cell (see section 4), but there are a number of differences. Phytohaemagglutinin cells, for example, often contain membrane-bound osmiophilic bodies which do not occur in the atypical mononuclear cells. The significance of these structures is unknown but Elves, Gough, Chapman, and Israëls (1964) suggest that they may represent accumulations of $\gamma$-globulin. (The relationship between atypical mononuclear cells and transformed lymphocytes is considered in more detail in Part II.)

\section{CYTOCHEMISTRY}

There are various cytochemical studies which include small numbers of cases of infectious mononucleosis (e.g., Hayhoe, 1953; Mitus, Bergna, Mednicoff, and Dameshek, 1958; Quaglino and Hayhoe, 1959) but few accounts deal with this condition in any detail (Galbraith, Mitus, Gollerkeri, and Dameshek, 1963). As with the electron-microscopic findings, the cytochemical properties of these cells do not bear out the pleomorphism which is apparent in conventional films. A reasonably consistent pattern of staining is seen which is summarized in Table I. Only two discrepancies have been noted.

\section{TABLE I}

CYTOCHEMICAL REACTIONS OF ATYPICAL MONONUCLEAR CELLS

Reaction

Positive Glycogen (P.A.S.-positive, diastase-sensitive material) ribosenucleic acid; lactic dehydrogenase; phosphorylase; acid phosphatase; non-specific esterase; reactive-SH groups

Negative Alkaline phosphatase; peroxidase; 'nadi'-oxidase

Equivocal Glycoproteins (P.A.S.-positive, diastase-resistant material); lipids

Unlike Galbraith et al. (1963), Carter (1965a) observed a few atypical mononuclear cells which contained diffuse, weakly-positive material stained by P.A.S. which was not removed by diastase. Secondly, like Hayhoe (1953), he was unable to detect any sudanophilic granules in the atypical cells.

Interpretation of these results is not easy. In some preparations it may be difficult to distinguish accurately between atypical mononuclear cells and normal large lymphocytes and monocytes; furthermore, there is still dispute over some patterns of staining in normal lymphoid cells. In several reactions, the difference between lymphocytes and monocytes is often relative rather than absolute. The general pattern of cytochemical staining in the 
atypical mononculear cells indicates that they are predominantly lymphocytic but they clearly do not fit exclusively into this category:-

(1) They contain phosphorylase and probably some P.A.S.-positive, diastase-resistant material. Both are usually absent from normal lymphocytes and from monocytes.

(2) Conversely, they appear to lack 'nadioxidase' which is usually present in normal lymphocytes and monocytes, a surprising finding as the particles stained in this procedure may be mitochondria (Hayhoe, 1963), which are well developed in the atypical cells.

(3) They contain large amounts of acid phosphatase, the normal distribution of which is still disputed. Some writers regard this as characteristic of lymphocytes (Rabinovitch and Andreucci, 1949; Haight and Rossiter, 1950), and others as more typical of monocytes (Galbraith et al., 1963).

(4) The ambiguities of lipid staining have already been mentioned.

Of the individual findings, the variable pyroninophilia is perhaps the most interesting, although it is emphasized that this reaction is usually moderate and confined to quite a small proportion of cells. The close correlation between basophilia, pyroninophilia, and RNA synthesis is now well established (White, 1947), and the question inevitably arises, Are these pyroninophilic forms young cells which are synthesizing structural proteins for growth, or are they mature cells forming 'extrinsic' proteins such as antibody globulins (c.f. plasma cells)? If the latter is true, do the increased amounts of P.A.S.positive material, particularly the diastase-resistant elements, perhaps represent the carbohydrate moiety of such proteins which, in the 19S $\gamma \mathrm{M}$ group of immune globulins, forms up to $10 \%$ of the total molecule (Franklin, 1964)? Evidence to be discussed later suggests that the first interpretation is the correct one and that the pyroninophilic elements are young cells which are not concerned with the synthesis of antibody proteins.

MITOTIC ACTIVITY, AUTORADIOGRAPHIC STUDIES, AND CHROMOSOME PATTERNS

Isolated binucleate and dividing cells have occasionally been noted in routine blood smears in infectious mononucleosis (Bowcock, 1939; Sundberg, 1960) and they can be demonstrated in a high proportion of white cell concentrates during the acute phase of the disease (Carter, 1965b). The majority of such cells are in prophase and metaphase; the relative scarcity of cells in the later stages of division probably reflects $(a)$ the shorter duration of telophase and anaphase characteristic of most other dividing blood cells (Japa, 1942; Cronkite, Bond, Fliedner, and Rubini, 1959) and (b) the deleterious effects of centrifugation and contact with anticoagulants. Dividing forms are fragile and may be particularly susceptible to damage at this stage.

Premitotic activity in the atypical mononuclear cells has now been investigated by various workers using autoradiographic techniques with tritiated $\left.{ }^{3} \mathrm{H}\right)$ thymidine, a specific nucleoside precursor of DNA (Gavosto, Pileri, and Maraini, 1959; Bertino, Simmons, and Donohue, 1962; Hale and Cooper, 1963; Epstein and Brecher, 1965; Carter, 1965b; Schmid, Oeschlin, and Moeschlin, 1965; MacKinney, 1965). In general, there is satisfactory agreement between the various results. Apart from Schmid et al. (1965), who observed no difference in labelling 'at initial or more advanced stages of the disease', most authors find that the uptake of ${ }^{3} \mathrm{H}$ thymidine is increased during the acute phase, falling back to the normal low levels between the fourth and sixth weeks. The maximum number of labelled forms varies between 5.0 and $9.5 \%$ in different series, although Bond, Fliedner, Cronkite, Rubini, Brecher, and Schork (1959) mention one case with $16.2 \%$ labelling. The label is confined to the nuclei of the atypical mononuclear cells. Many of these show increased cytoplasmic basophilia but this is not a constant finding and the cytoplasm of some labelled cells is distinctly pale. In the study by Bertino et al. (1962), ${ }^{3} \mathrm{H}$-thymidine uptake is well correlated with increased levels of certain enzymes known to be involved in folic acid metabolism. (A few accounts also include autoradiographic studies with ${ }^{3} \mathrm{H}$ cytidine to investigate RNA synthesis. In general, the pattern of uptake is similar to that described for ${ }^{3} \mathrm{H}$-thymidine and it appears that increased DNA and RNA synthesis moves in parallel.)

Interpretation of the increased uptake of ${ }^{3} \mathrm{H}$ thymidine by atypical mononuclear cells is not entirely straightforward and various problems arise.

1 Nuclear labelling combined with the distortions produced during the preparation of white cell concentrates may obscure fine structural detail. Appraisal of cytological features suggesting relative maturity or immaturity of the labelled cells is therefore difficult and their precise characterization, e.g., as lymphocytoid, monocytoid, or plasmacytoid types (Schmid et al., 1965), is hard to evaluate.

2 Some workers have suggested that the increased ${ }^{3} \mathrm{H}$-thymidine uptake might indicate impending synthesis of viral, rather than cellular, DNA (Gavosto et al., 1959; Bertino et al., 1962). But no virus particles have been demonstrated in electronmicroscopic studies (Reinauer, 1961; Paegle, 1961), and work by Hale and Cooper (1963) has clearly 
demonstrated that it is cellular DNA which is being formed.

3 Not all atypical cells labelled with ${ }^{3} \mathrm{H}$ thymidine go on to divide (Epstein and Brecher, 1965; MacKinney, 1965). The reasons for this 'abortion rate' in vitro are obscure and it is uncertain how closely such changes mirror events which occur in vivo.

Three further observations may be made. First, this considerable mitotic activity is not accompanied by detectable chromosome abnormalities. Visual karyotype analyses are consistently normal (Carter, 1965b). Secondly, virtually nothing is known about the progeny of the dividing cells. Gavosto et al. (1959) postulated that the atypical cells might be totipotent, perhaps comparable to members of the 'mobile pool of primitive progenitor cells' described by Bond et al. (1959), but there is no evidence for this view. MacKinney (1965) suggests that they give rise to 'small round cells resembling lymphocytes' in vitro, but this is clearly a field for further investigation. Lastly, it is emphasized that all these studies have dealt solely with peripheral blood: since the great majority of atypical mononuclear cells lie outside the vascular compartment in the tissues (Custer and Smith, 1948; Goldberg, 1962), it appears that the overall proliferative activity among these cells is likely to be considerable.

\section{ATYPICAL MONONUCLEAR CELLS AND ANTIBODY FORMATION}

Before considering atypical mononuclear cells as possible sites of antibody synthesis, a few recent observations on the general pattern of antibody formation in infectious mononucleosis will be briefly mentioned:-

1 The Paul-Bunnell antibody falls into the high molecular weight 19S $\gamma \mathrm{M}$ group of antibodies (Kunkel, Fudenberg, and Ovary, 1960; Wilkinson and Carmichael, 1964; Carter, 1966a); no 7S ( $\gamma \mathrm{G})$ component has yet been demonstrated, particularly during the later phases of the disease when, in most other systems, $7 \mathrm{~S}$ antibodies commonly appear.

2 Many of the 'false-positive' serological reactions which occur in this disease are also mediated by $19 \mathrm{~S} \gamma \mathrm{M}$ elements, sensitive to mercaptoethanol (Jenkins, Koster, Marsh, and Carter, 1965; Carter, 1966b).

3 There is an overall increase in $\gamma \mathrm{M}$ globulin levels, shown qualitatively by enhanced $\gamma \mathrm{M}$ precipitin arcs on immunoelectrophoresis (Carter, 1966a), and quantitatively, by gel diffusion techniques (Wollheim and Williams, 1966). It should be emphasized that this increase in $\gamma \mathrm{M}$ elements does not occur at the expense of other immunoglobulins and that the normal preponderance of 7S $\gamma$-globulins is retained: $\gamma \mathrm{G}$ globulin precipitin arcs are normal or moderately increased on immunoelectrophoresis while the $\gamma \mathrm{A}$ lines are unchanged.

The cellular localization of antibody globulins in infectious mononucleosis has received little attention and the few data available can be summarized as follows. Immunofluorescent studies on white cell concentrates have usually failed to demonstrate any staining in the atypical mononuclear cells (Evans, 1960; Galbraith et al., 1963); some fluorescent staining was described in concentrates from one patient by Duheille, Herbeuval, and Fourot (1963) but no details are given as to the number or morphology of these cells. Very occasional fluorescing cells were recently observed in concentrates by Carter (1966c) but their scarcity is emphasized and efforts to demonstrate antibody production by the circulating cells with other equally refined methods, e.g., using modifications of the Coombs mixed cell agglutination technique, were unsuccessful. Earlier attempts to demonstrate production of the PaulBunnell antibody by leucocytes cultured in vitro gave negative results, and experiments in which washed cells were disrupted with ultrasonics produced no evidence of pre-formed intracellular antibody. (It will be obvious that procedures of this kind are only suitable for demonstrating relatively large-scale effects.) Slightly more encouraging results have come from occasional studies of lymph nodes and bone marrow although opportunities for such work are severely restricted. Sections of whole nodes, for example, have apparently not been examined from this viewpoint but there is some information from lymph-node and bone-marrow aspirates. The limitations of the aspiration technique, particularly sampling errors, are obvious and the results obtained need to be interpreted with caution. Galbraith et al. (1963) described fluorescent cells in lymph node aspirates but did not record the types of Coombs reagent used. Parallel stained smears contained large basophilic cells characterized as haemocytoblasts (c.f. Fagraeus, Good, White, and Holub, 1962) or immunoblasts (c.f. Dameshek, 1963) which were thought to be the fluorescing elements. No staining was observed in the atypical mononuclear cells. Using a conjugated anti $\gamma$-M globulin serum, Carter (1966c) demonstrated moderate numbers of fluorescing cells in material from nodes and bone marrow; these were infrequently seen in control material, particularly in normal bone marrow. Similar cells, present in larger numbers, were readily stained with an anti $7 \mathrm{~S}(\gamma \mathrm{G})$ globulin antiserum. The fluorescing elements were rather small (about $10 \mu$ in diameter) with regular cell outlines and eccentric, oval, sometimes indented, nuclei; a few other cells, probably less mature, were 
seen in the smears from lymph nodes and bone marrow which were larger with less cytoplasm and big central nuclei.

The identity of these stained elements is uncertain. Their appearance in the fluorescence microscope gives only an approximate guide to their true nature and subsequent direct staining of such preparations with Romanowsky dyes is unsatisfactory, as cytological detail is not well preserved after exposure to ultra-violet light. Reliance has to be placed on parallel smears and correlation of cell types in separate preparations is clearly less satisfactory. However, two tentative interpretations may be considered. (1) The stained cells may be precursors of the atypical mononuclear cells. Three objections may be raised against this view. Few of the fluorescing cells show obvious morphological features of immaturity and they are not particularly common in the 'central' lymphoid tissues where atypical mononuclear cells are presumably formed. Thirdly, immature lymphoid cells, at least with respect to DNA and RNA synthesis, form 5 to $10 \%$ of the circulating atypical cells, far in excess of the numbers of fluorescing cells in the blood. (2) Alternatively, the stained cells may be members of the plasma cell series rather than atypical mononuclear cells. The difficulties in establishing this are immediately apparent but two preliminary points may be mentioned. The fluorescing cells have a decidedly 'plasmacytoid' appearance and differ from atypical mononuclear cells with respect to their smaller size and consistently regular cell outlines. Secondly, their incidence in the three types of preparation is characteristic of the known distribution of plasma cells in white cell concentrates, bone marrow, and lymph nodes in infectious mononucleosis. The issue may be clarified by future studies, particularly on whole nodes, but at present there is no certain evidence to link atypical mononuclear cells with antibody synthesis. Various collateral observations, especially on the ultrastructure of the atypical cells, support this view.

\section{MISCELLANEOUS OBSERVATIONS}

EFFECTS OF PHYTOHAEMAGglutinin (PHA) Atypical mononuclear cells have sometimes been compared to lymphocytes which have been transformed by PHA (Pearmain and Lycette, 1963; Elves et al., 1964; Schmid et al., 1965) but there have been few efforts to substantiate these claims. If the atypical cells are truly mature lymphocytes which have been transformed in vivo, one would suspect that such changes might continue under suitable conditions in vitro, at least during the initial stages of the disease, irrespective of the presence of PHA although the process might well be enhanced by this substance. Leucocyte concentrates are, of course, extremely pleomorphic in infectious mononucleosis but grossly immature cells resembling 'blasts' are not common and any sizable increase in their numbers should be detectable. No clear-cut increase in such cells has, however, been observed in cultures with or without PHA (Carter, unpublished observations); MacKinney (1965) has reported that there is a (late) increase in the numbers of cells undergoing mitosis in cultures containing PHA but he does not mention any morphological changes.

The failure of the atypical cells to transform in the presence of PHA raises two possibilities. (1) This process has already occurred in vivo and the cultures are composed of fully transformed cells; (2) the cells are unable to transform, because $(a)$ they are immature lymphocytes in which this response has not yet developed, $(b)$ they are derived from 'lymphoid' cells other than lymphocytes which are normally unresponsive, or $(c)$ they are abnormal forms analogous to lymphocytes from cases of chronic lymphatic leukaemia, lymphosarcoma, or Hodgkin's disease which are also resistant to PHA (Quaglino and Dowling, 1964; Hersh and Oppenheim, 1965). The first of these possibilities is fully discussed in Part II of this review but at present there is no evidence to suggest that atypical mononuclear cells are analogous to PHA cells. The alternative interpretations raised in (2) will also be considered later but two points may be noted now. First, there is no reason $a$ priori to suppose that the atypical cells are abnormal elements (see $2 c)$; secondly, the two other possibilities $(2 a, 2 b)$ are entirely compatible not only with each other but with certain views on the heterogeneous nature and origin of the atypical cells (v.i.).

ANTIGENIC STRUCTURE This has apparently received no attention and only one purely empirical observation may be mentioned, namely, that atypical mononuclear cells are regularly clumped by leucoagglutinating sera (Carter, unpublished observations). This is of some interest when comparing the atypical cells with leukaemic blast cells as the latter are not agglutinated by such sera (Killmann, 1960).

\section{PART II}

ATYPICAL MONONUCLEAR CELLS AND 'TRANSFORMED' LYMPHOCYTES

Certain features common to both atypical mononuclear cells and transformed lymphocytes (PHA cells) have already been mentioned but their significance is uncertain. Thus on morphological grounds, the two types of cell are undoubtedly 
similar but PHA cells are extremely pleomorphic and they have also been likened to myeloblasts, erythroblasts, lymphoblasts, plasmablasts, proerythroblasts from megaloblastic bone marrow, and reticulum cells (Carstairs, 1962; Elves et al., 1964). Again there are similarities in ultrastructure but these seem to reflect, for the most part, the enhanced DNA synthesis which occurs in both cells. Both show increased ${ }^{3} \mathrm{H}$-thymidine uptake in vitro, but a much higher proportion of nuclear labelling takes place in PHA cells (Cooper, Barkhan, and Hale, 1963). There are also differences in cytochemical staining: PHA cells contain little glycogen (except in the very earliest stages of transformation), no phosphorylase, and little non-specific esterase (Quaglino, Hayhoe, and Flemans, 1962); they are also intensely and uniformly pyroninophilic. Few if any atypical mononuclear cells can be stained by immunofluorescent techniques but some authors claim that PHA cells are readily stained by such procedures (Elves, Roath, Taylor, and Israëls, 1963; Bach and Hirschhorn, 1963), a finding which is difficult to reconcile with the generally unremarkable endoplasmic reticula in these cells. Many other aspects of transformed lymphocytes are also controversial and a comparison with atypical mononuclear cells may seem premature; but the information available at present suggests that they are probably separate entities.

\section{THE ORIGIN OF ATYPICAL MONONUCLEAR CELLS}

Lacking clear evidence that atypical mononuclear cells arise by transformation of mature lymphocytes, it is necessary to reconsider the old view, that these cells are formed de novo within lymphoid tissues. It has often been shown that atypical mononuclear cells, which are similar to those seen in the blood, are present in imprints of lymph nodes (e.g., Downey and Stasney, 1936; Strunge, 1944; Sundberg, 1947; Lucas, 1955); as they are clearly 'lymphoid' elements it is reasonable to suppose that they may arise in situ, particularly as cells indistinguishable from these occur not only in many other hyperplastic nodes (irrespective of the underlying aetiology), but also in normal lymphoid tissues. Downey and Stasney (1936) regarded many of the atypical mononuclear cells as intermediate forms in the development of small lymphocytes from reticulum cells, a normal process which is enhanced in nodes showing reactive hyperplasia, of which infectious mononucleosis is an extreme example. The unusual feature of this disease is that the intense reticulum cell hyperplasia (differentiating mainly towards lymphoid elements) is apparently unaccompanied by any corresponding increase in the numbers of mature lymphocytes either in the circulation or, more significantly, in the tissues; instead large numbers of atypical mononuclear cells occur at these sites. Two hypotheses may be considered which could combine to explain this somewhat paradoxical state of affairs.

1 There is proliferation of reticulum cells and early lymphocyte precursors but full maturation is temporarily impaired. This causes a progressive 'shift to the left' and increasing numbers of immature cells accumulate in the tissues and appear in the blood. The changes in the lymphoid tissues and in the blood, particularly with regard to DNA- and RNA-synthesizing cells, are fully compatible with this view. Its main weakness is that it commits all the atypical cells to a definite lymphocytic origin which is difficult to reconcile with the appearance of some of the cells in stained films, their ultrastructure, and their cytochemistry. These problems are largely resolved if the atypical mononuclear cells are regarded as a more heterogeneous group in which lymphocytic elements are the principal but not the only components: the second hypothesis, which is a good deal more speculative, is concerned with this minority of 'other lymphoid cells'.

2 A proportion of reticulum cells and early lymphocyte precursors develops into various lymphoid cells other than lymphocytes but which are closely related to them. Such cells fall into two categories: (a) they may be related to normal lymphoid cells, i.e., to monocytes and plasma cells; (b) some may be derived from abnormal lymphoid elements (perhaps produced as a consequence of the great increase in lymphoreticular proliferation) which may have a wide range of more of less 'lymphocytoid', 'monocytoid', or 'plasmacytoid' features. As cells in the normal developmental span between reticulum cells and lymphocytes retain their ability to take up ${ }^{3} \mathrm{H}$-thymidine and divide right up to the stage of the small lymphocyte (Yoffey, 1962), a temporary, partial diversion to form other types of closely related lymphoid cells could clearly occur at various points in the developmental pathway.

In view of the controversies which still surround the development of lymphocytes and their relationship to monocytes and to plasma cells, there will be little need to stress the tentative nature of these ideas. The limitations of the traditional criteria of 'maturity' and 'immaturity' when applied to lymphoid cells are now all too apparent and, as Policard (1963) has observed, 'ce qui est possible n'est pas nécéssairement ce qui est'.

ATYPICAL MONONUCLEAR CELLS AND LEUKAEMIC CELLS

Infectious mononucleosis can simulate acute leukaemia to an alarming degree and a close relation- 
ship between the two diseases has often been postulated. Thus Dameshek and Gunz (1964) consider that infectious mononucleosis 'satisfies almost every definition of leukaemia that one can make' and suggest that it may even constitute 'an atypical form of acute leukaemia with a self-limiting course in which reversal to normal always takes place'. Lacking an aetiology for either condition, it may be that detailed comparisons are premature, particularly as it is still so difficult to categorize the unique features of leukaemic proliferation. There are, however, a number of points which, at least in aggregate, suggest that the resemblance between atypical mononuclear cells and leukaemic blast cells is perhaps less than may appear at first sight.

The circulating atypical mononuclear cells are, once again, strikingly pleomorphic in contrast to the 'deadly monotony' (Dameshek and Gunz) of leukaemic cells. Individual atypical cells rarely resemble leukaemic blasts: obviously immature, nucleolated forms may occur but the nuclear chromatin in such cells is usually finer and more reticulated, and the cytoplasm is typically more abundant and basophilic. The presence of dividing cells in the circulation is a surprising finding in the benign condition but more detailed studies indicate that mitotic activity, although strikingly enhanced, is not fundamentally deranged. DNA synthesis follows a normal pattern and chromosome analyses have shown no qualitative or quantitative abnormalities. Similar data with respect to leukaemic blast cells are more controversial but the proportion of cells which can be labelled with ${ }^{3} \mathrm{H}$-thymidine is usually abnormally low (Gavosto, Maraini, and Pileri, 1960), the subsequent patterns of DNA synthesis are sometimes abnormal (Petrakis, 1953; Hale and Wilson, 1960; Hale and Cooper, 1963), and there is a high incidence of chromosomal abnormalities (Ford, 1961; Gunz and Fitzgerald, 1964). Ultrastructure and patterns of cytochemical staining are of little value in comparing atypical mononuclear cells and leukaemic blasts, and any differences in antigenic structure remain to be discovered, although mention may be made of the effects of leuco-agglutinating sera which regularly clump atypical mononuclear cells but do not agglutinate blast cells.

Cytological studies of lymphoid tissues indicate that the atypical cells are normal components which increase in any condition producing reactive hyperplasia: lymphoreticular proliferation in infectious mononucleosis thus involves, for the most part, normal cell elements. Although violent, it is always completely reversible and, even at its height, the nodal architecture is never completely overthrown (Downey and Stasney, 1936; Gall and Stout, 1940; Custer and Smith, 1948). The histological picture is not specific and some authors (e.g., Marshall, 1956) include infectious mononucleosis in the category of lymphohistiocytic medullary reticulosis (RobbSmith, 1947). Similar changes occur widely throughout the lymphoid tissues but it is generally agreed that bone marrow involvement is trivial: non-specific granulomata may occur (Campbell, 1948) and there may be a little intramedullary lymphopoiesis (Hovde and Sundberg, 1950), but haemopoiesis is unaffected.

Occasional cases of infectious mononucleosis are complicated by overt anaemia, agranulocytosis and thrombocytopenia, and smaller (subclinical) reductions, at least in granulocytes (Carter, 1966d) and in platelets (Carter, 1965c), are surprisingly common. The factors responsible for such changes are illunderstood. The appropriate bone-marrow precursors are almost always present in normal or increased numbers and the relevant mechanisms seem to be acting peripherally rather than centrally ( $c f$. the acute leukaemias). This view is supported by recent work showing an unexpectedly high incidence of the potentially lytic antibody anti-i (Jenkins et al., 1965; Rosenfield, Schmidt, Calvo, and McGinniss, 1965) and, rather less convincingly, by the occurrence of leuco-agglutinins and anti-platelet factors. By contrast, almost all workers regard the leukaemic blast cells as an abnormal alien which proliferates and overruns normal lymphoid tissues in a process which is ultimately irreversible; involvement of bone marrow to produce early and profound depression of normal haemopoiesis is a cardinal feature.

\section{REFERENCES}

Bach, F., and Hirschhorn, K. (1963). Exp. Cell Res., 32, 592.

Bertino, J. R., Simmons, B. M., and Donohue, D. M. (1962). Blood, $19,587$.

Bond, V. P., Fliedner, T. M., Cronkite, E. P., Rubini, J. R., Brecher, G., and Schork, P. K. (1959). Acta haemat. (Basel), 21, 1.

Bowcock, H. (1939). Amer. J. med. Sci., 198, 384.

Campbell, A. C. P. (1948). J. Path. Bact., 60, 629.

Carstairs, K. (1962). Lancet, 1, 829.

Carter, R. L. (1965a). The cytology and immunology of infectious mononucleosis, D.M. Thesis. University of Oxford. (1965b). Blood, 26, 579.

(1965c). Ibid., 25, 817.

- (1966a). Brit. J. Haemat., 12, 259.

(1966b). Ibid, 12, 268.

- (1966c). Amer. J. clin. Path., 45, 574.

- (1966d). J. clin. Path., 19, 279.

Cooper, E. H., Barkhan, P., and Hale, A. J. (1963). Brit. J. Haemat., 9,101 .

Cronkite, E. P., Bond, V. P., Fliedner, T. M., and Rubini, J. R. (1959). Lab. Invest., 8, 263.

Custer, R. P., and Smith, E. B. (1948). Blood, 3, 830.

Dameshek, W. (1963). Ibid., 21, 243.

- , and Gunz, F. (1964). Leukemia. Grune and Stratton, New York.

Downey, H., and McKinlay, C. A. (1923). Arch. intern. Med., 32, 82.

- , and Stasney, J. (1936). Folia haemat. (Lpz.), 54, 417.

Duheille, J., Herbeuval, H., and Fourot, M. (1963). C.R. Soc. Biol. (Paris), 157, 591.

Efrati, P., and Rozenszajn, L. (1960). Blood, 16, 1012.

Elves, M. W., Gough, J., Chapman, J. A., and Israëls, M. C. G. (1964). Lancet, 1, 306.

_, Roath, S., Taylor, G., and Israëls, M. C. G. (1963). Ibid., 1, 1292. Epstein, L. B., and Brecher, G. (1965). Blood, 25, 197. 
Evans, A. S. (1960). Amer. J. Hyg., 71, 342

Fagraeus, A., Good, R. A., White, R. G., and Holub, M. (1962). In Mechanisms of Antibody Formation, Edited by M. Holub. Czechoslovak Academy of Sciences, Prague.

Ford, C. E. (1961). Nouv. Rev. Franc. Hémat., 1, 165.

Franklin, E. C. (1964). Progr. Allergy, 8, 58.

Galbraith, P., Mitus, W. J., Gollerkeri, M., and Dameshek, W. (1963). Blood, 22, 630 .

Gall, E. A., and Stout, H. A. (1940). Amer. J. Path., 16, 433.

Gavosto, F., Maraini, G., and Pileri, A. (1960). Blood, 16, 1555.

_-, Pileri, A., and Maraini, G. (1959). Nature, (Lond.), 183, 1691.

Giacardy, R., and Giacardy, P. (1961). Nouv. Rev. Franc. Hemat., 1, 349.

Goldberg, G. M. (1962). Cancer (Philad.), 15, 869.

Gunz, F. W., and Fitzgerald, P. H. (1964). Blood, 23, 394.

Haight, W. F., and Rossieter, R. J. (1950). Ibid., 5, 267.

Hale, A. J., and Wilson, S. J. (1960). Lancet, 1, 577.

- and Cooper, E. H. (1963). Acta haemat. (Basel), 29, 257.

Hayhoe, F. G. J. (1953). J. Path. Bact., 65, 413.

- (1963). In Disorders of the Blood, by L. E. H. Whitby, and C. J. C. Britton, 9th ed., p. 131, Churchill, London.

Hersh, E. M., and Oppenheim, J. J. (1965). New Engl. J. Med., 273, 1006.

Hovde, R. F., and Sundberg, R. D. (1950). Blood, 5, 209.

Inman, D. R., and Cooper, E. H. (1965). Acta haemat. (Basel), 33, 257.

Japa, J. (1942). Brit. J. exp. Path., 23, 272.

Jenkins, W. J., Koster, H. G., Marsh, W. L., and Carter, R. L. (1965). Brit. J. Haemat., 11, 480.

Killmann, S. A. (1960). Leukocyte Agglutinins. Blackwell Scientific Publications, Oxford.

Kunkel, H. G., Fudenberg, H. H., and Ovary, Z. (1960). Ann. N.Y. Acad. Sci., 86, 966.
Litwins, J., and Leibowitz, S. (1951). Acta haemat. (Basel), 5, 223.

Lucas, P. F. (1955). Blood, 10, 1030.

MacKinney A. A. Jr. (1965). Ibid., 26, 36.

Marshall, A. H. E. (1956). An Outline of the Cytology and Pathology of the Reticular Tissues. Oliver and Boyd: Edinburgh.

Mitus, W. J., Bergna, L. J., Mednicoff, I. B., and Dameshek, W. (1958) Blood, 13, 748

Paegle, R. D. (1961). Ibid., 17, 687.

Pearmain, G. E., and Lycette, R. R. (1963). Lancet, 2, 1032.

Petrakis, N. L. (1953). Blood, 8, 905.

Policard, A. (1963). Physiologie et Pathologie du Système Lymphoide. Masson, Paris.

Quaglino, D., and Dowling, D. C. (1964). Brit. J. Haemat., 10, 358.

- and Hayhoe, F. G. J. (1959). J. Path. Bact., 78, 521.

- , and Flemans, R. J. (1962). Nature (Lond.), 196, 338

Rabinovitch, M., and Andreucci, D. (1949). Blood, 4, 580.

Reinauer, H. (1961) Folia haemat. (Frankfurt), 5, 296.

Robb-Smith, A. H. T. (1947). In Recent Advances in Clinical Pathology, Edited by S. C. Dyke, p. 350, Churchill, London.

Rosenfield, R. E., Schmidt, P. J., Calco, R. C., and McGinniss, M. H. (1965). Vox Sang. (Basel), 10, 631.

Schmid, J. R., Oeschlin, J., and Moeschlin, S. (1965). Scand. J. Haemat $2,18$.

Strunge, J. (1944). La Ponction des Ganglions Lymphatiques. Munksgaard, Copenhagen.

Sundberg, R. D. (1947). J. Lab. clin. Med., 32, 777.

(1960). In The Lymphocyte and Lymphocytic Tissue, Edited by J. W. Rebuck, p. 1. Hoeber, New York.

White, J. C. (1947). J. Path. Bact., 59, 223.

Wilkinson, P. C., and Carmichael, D. S. (1964). J. Lab. clin. Med., 64 529.

Yoffey, J. M. (1962). Lancet, 1, 206. 